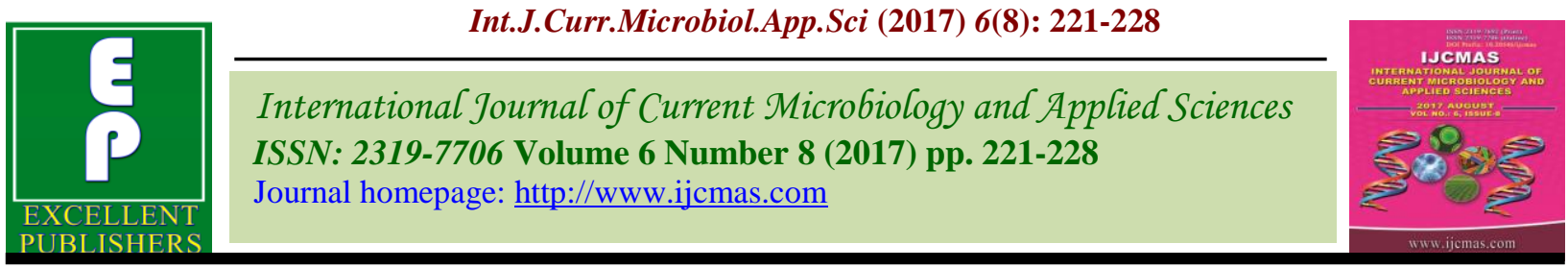

Original Research Article

https://doi.org/10.20546/ijcmas.2017.608.030

\title{
Seroprevalence of Peste des Petits Ruminants (PPR) in Navsari and Valsad Districts of South Gujarat
}

\author{
Yash R. Patel $^{1 *}$, Jignesh M. Patel ${ }^{1}$, Priti D. Vihol ${ }^{1}$, I.H. Kalyani ${ }^{2}$, \\ Pramod S. Sakare ${ }^{2}$, Pratik P. Panchal ${ }^{1}$ and Kaushik D. Thakor ${ }^{1}$
}

${ }^{1}$ Department of Veterinary Pathology, ${ }^{2}$ Department of Veterinary Microbiology, Vanbandhu College of Veterinary Sciences and Animal Husbandry, Navsari Agricultural University,

Navsari-396 450, Gujarat, India

*Corresponding author

\section{A B S T R A C T}

Keywords

C-ELISA,

Goat, Haemato-

biochemical

parameters,

Seroprevalence,

PPR.

Article Info

Accepted:

04 June 2017

Available Online:

10 August 2017
In the present study, a total $210 \mathrm{blood} / \mathrm{serum}$ samples were collected from goats housed in various farms, local flocks and panjarapoles located in Navsari and Valsad districts screened for Peste des petits ruminants (PPR) specific antibodies using PPR C-ELISA kit. Out of 210 serum samples 99 were found positive for PPR antibodies with overall seroprevalence of 47.14 per cent. District wise the seroprevalence in Navsari and Valsad districts was 60.44 per cent and 23.68 per cent, respectively. Females of this species showed higher seroprevalence (56.20, $86 / 153)$ rate in comparison to their counterpart male $(22.80,13 / 57)$. Seroprevalence was comparatively higher in November $(90 \%)$ followed by December (59.25\%), January (52.17\%) and August (11.11\%) month. The age-wise seroprevalence was 68 per cent and 36.36 per cent in $<1$ year and 1 to 3 years of age group, respectively. Interpretation of complete blood count result shown decrease in $\mathrm{Hb}, \mathrm{PCV}$, monocytes and $\mathrm{MCV}$ value of seropositive group when compared with seronegative group. While biochemical parameters, ALT, ALP level and creatinine value were increased in seropositive groups of animals.

\section{Introduction}

Peste des petits ruminants (PPR) is an acute febrile viral disease of goats and sheep caused by RNA virus belonging to the genus Morbillivirus of Paramyxoviridae family (Gibbs et al., 1979). PPR is also known as kata, stomatitis- pneumoentritis complex, goat plaque and pseudo- rinderpest (Jubb et al., 2007). The disease is highly contagious causing varying degree of morbidity and mortality in susceptible animals (Radostits et al., 2007).
In India, PPR was first reported in 1987 from Tamil Nadu (Shaila et al., 1989) and it continues to be present in the Southern India until 1994. Later, a number of PPR outbreaks were reported from the northern states of India (Nanda et al., 1996) with a solitary report in Indian buffalo in southern state (Govindarajan, 1997). The previous reports documented the presence of PPRV in Rajasthan in the north (Kataria et al., 2007), Kolkata region in the east (Saha et al., 
2005), Karnataka in the south (Chavan et al., 2009) and Maharastra in the west (Santhosh et al., 2009) and across the southern peninsula (Raghavendra et al., 2008).

PPRV was serologically confirmed from Gujarat by Hinshu et al., (2001) followed by many researchers (Tiwari, 2004, Kanani et al., 2006, Nagraj, 2006, Balamurugan et al., 2011 and Chandrahas et al., 2011). Recently, an outbreak of PPR was reported in Navsari and Valsad district of Gujarat (Sharma et al., 2015 and Thakor et al., 2016).

Organized clinical surveys or confirmation of outbreak status has not been performed for PPR in India except for a few isolated clinical reports from different State Animal Husbandry Departments (Singh et al., 2004). The majority of these reports except for the one by Singh et al., (2004) included only regional data from various states of India since 1994. Hence present experiment has been carried out to known status of PPR in two districts of South Gujarat.

\section{Materials and Methods}

A total of $210 \mathrm{blood} / \mathrm{serum}$ samples collected from goats housed in various farms, local flocks and panjarapoles located in Navsari and Valsad districts were screened for PPR specific antibodies using PPR CELISA kit. The tested serum samples showing less than $50.00 \%$ inhibition of mean OD values of wells were considered as positive for PPR antibodies.

PPRV antibody was detected by PPR CELISA kit obtained from IDvet, FRANCE. The competition percentage (S/N \%) was calculated for each sample and then grouped as positive ( $\mathrm{S} / \mathrm{N} \% \leq 50 \%)$, negative $(\mathrm{S} / \mathrm{N} \%>$ $60 \%)$ or doubtful $(50 \%<\mathrm{S} / \mathrm{N} \% \leq 60 \%)$. Various haematological parameters such as
$\mathrm{Hb}, \mathrm{PCV}, \mathrm{TEC}, \mathrm{TLC}, \mathrm{MCV}, \mathrm{MCH}$, and $\mathrm{MCHC}$ were estimated by using fully auto hematology cell counter (Exigo EOS Hematology Analyzer) while Differential Leukocyte Count (DLC) was done manually by screening blood smear.

Serum biochemical parameters such as Creatinine, ALP, AST and ALT were analyzed using Reactivos GPL kits (CHEMELEX, S. A., Pol. Ind. Can Castells. C/ Industria 113, Nau J, 08420 CanovellesBARCELONA) in semi- automatic biochemical analyzer (Micro lab Instrument, Model: ARX-3 in 1).

\section{Results and Discussion}

The district-wise, month-wise, sex-wise and age-wise seroprevalence details are given in table 2. Out of 210 serum samples tested, 99 were found positive for PPR antibodies yielding an overall seroprevalence of 47.14 per cent in the goats of the Navsari and Valsad districts. Where Navsari district saw higher seroprevalence (60.44\%) compare to Valsad districts $(23.68 \%)$. Though Thakor et al., (2016) and Sharma et al., (2015) reported high prevalence of PPR in Valsad district of south Gujarat. Present study report might be due to variations in sample size, age, predominant management practices, humidity or season (Singh et al., 2004).

In the present study, the seroprevalence of PPR disease was higher in female $(56.20 \%)$ than male $(22.80 \%)$ and supported by earlier reports of El-Yuguda et al., (2013), Mahajan et al., (2013), Afera et al., (2014), Nizamani et al., (2015), Bello et al., (2016) and Rahman et al., (2016 and 2017). Contrary to these observations, sex wise seroprevalence of PPR was also reported higher in male than female (Thakor et al., 2016). Higher prevalence in female than male in present study might be due to malnutrition, production and 
reproduction stress which makes female more prone to infection.

Further, the seroprevalence was comparatively higher in November (90 \%) followed by December (59.25\%), January (52.17\%) and August (11.11\%) month. Mahajan et al., (2013) also noted steady incidence of 50 per cent during the month November, December and January which increased in the month of February and March up to 100 per cent.

Similarly, Singh et al., (2004) noted higher seroprevalence between the months of March and June. In the present study, higher prevalence in the November and December months might be due to increase demand of goats during festivals like Christmas and Bakra eid. To cop up the demand of chevon, goats were transported from Rajasthan to Gujarat and travelling of long distance was one of the main exciting cause for the occurrence of PPR.
The age-wise seroprevalence was 68 per cent and 36.36 per cent in $<1$ year and 1 to 3 years of age group, respectively, while no seropositivity was found in any one of goat having age more than 3 years.

Similarly, Mahajan et al., (2013), Afera et al., (2014), Bello et al., (2016) and Thakor et al., (2016) also opined young animals were more susceptible to PPR infection compare to adults animals. Among these, Begum et al., (2016) and De et al., (2016) reported higher seroprevalence rate in $>6$ months of age than <6months. However, Chauhan et al., (2012), El-Yuguda et al., (2013), Nizamani et al., (2015) and Rahman et al., (2017) have been reported higher seroprevalence in adult than young animals. The higher seroprevalence in younger animal might be due to sub-clinical load of coccidial/parasitic infection which causes immune-suppressive effect or $E$. coli infection causes fimbrial adhesion with intestinal mucosa which enhances effect of PPR virus (Kumar et al., 2001).

Table.1 Hematological parameters in control and PPR infected goats (mean \pm SE)

\begin{tabular}{|c|c|c|c|c|}
\hline \multirow[t]{2}{*}{ Sr. No. } & Parameters & $\begin{array}{c}\text { Seronegative } \\
\quad(n=111)\end{array}$ & $\begin{array}{c}\text { Seropositive } \\
\quad(n=99)\end{array}$ & $P$ value \\
\hline & \multicolumn{4}{|c|}{ Mean \pm SE } \\
\hline 1. & $\mathrm{Hb}$ & $8.34 \pm 0.19$ & $6.97 \pm 0.17 * *$ & $<0.001$ \\
\hline 2. & PCV & $22.39 \pm 0.49$ & $19.66 \pm 0.48 * *$ & $<0.001$ \\
\hline 3. & TEC & $13.06 \pm 0.37$ & $12.34 \pm 0.31^{\mathrm{NS}}$ & 0.15 \\
\hline 4. & TLC & $11.45 \pm 0.70$ & $11.11 \pm 0.52^{\mathrm{NS}}$ & 0.69 \\
\hline \multirow[t]{6}{*}{5.} & DLC & & & \\
\hline & Neutrophils & $48.88 \pm 1.60$ & $49.45 \pm 1.53^{\mathrm{NS}}$ & 0.79 \\
\hline & Eosinophils & $1.28 \pm 0.20$ & $1.38 \pm 0.25^{\mathrm{NS}}$ & 0.76 \\
\hline & Basophils & $0.02 \pm 0.02$ & $0.00 \pm 0^{\mathrm{NS}}$ & 0.34 \\
\hline & Monocytes & $5.64 \pm 0.42$ & $3.83 \pm 0.37 *$ & $<0.01$ \\
\hline & Lymphocytes & $41.45 \pm 1.61$ & $45.36 \pm 1.54^{\mathrm{NS}}$ & 0.08 \\
\hline 6. & $\mathrm{MCV}$ & $18.29 \pm 0.50$ & $16.30 \pm 0.36^{*}$ & $<0.01$ \\
\hline 7. & $\mathrm{MCH}$ & $7.66 \pm 0.84$ & $6.61 \pm 0.94^{\mathrm{NS}}$ & 0.40 \\
\hline 8. & $\mathrm{MCHC}$ & $36.30 \pm 0.40$ & $38.52 \pm 3.45^{\mathrm{NS}}$ & 0.49 \\
\hline
\end{tabular}


Table.2 District, month, age and sex wise seroprevalence of PPR in goats

\begin{tabular}{|c|c|c|c|}
\hline Particular & No. of samples & $\begin{array}{l}\text { No. of samples } \\
\text { Positive }\end{array}$ & $\begin{array}{c}\text { Percentage of } \\
\text { Positive samples }\end{array}$ \\
\hline \multicolumn{4}{|l|}{ District } \\
\hline Navsari & 134 & 81 & 60.44 \\
\hline Valsad & 76 & 18 & 23.68 \\
\hline $\begin{array}{l}\text { Total } \\
\chi^{2}=24.84 * *\end{array}$ & $0.001)^{210}$ & 99 & 47.14 \\
\hline \multicolumn{4}{|c|}{ Months } \\
\hline August & 27 & 3 & 11.11 \\
\hline September & 39 & 0 & 0 \\
\hline November & 40 & 36 & 90 \\
\hline December & 81 & 48 & 59.25 \\
\hline January & 23 & 12 & 52.17 \\
\hline \multicolumn{4}{|c|}{$\chi^{2}=83.34 * *(p<0.001)$} \\
\hline \multicolumn{4}{|c|}{ Age } \\
\hline$<1$ Year & 75 & 51 & 68 \\
\hline 1-3 Year & 132 & 48 & 36.36 \\
\hline$>3$ Year & 3 & 0 & 0 \\
\hline $\begin{array}{l}\text { Total } \\
\chi^{2}=21.92 * *\end{array}$ & $0.001)^{210}$ & 99 & 47.14 \\
\hline \multicolumn{4}{|c|}{ Sex } \\
\hline Male & 57 & 13 & 22.80 \\
\hline Female & 153 & 86 & 56.20 \\
\hline $\begin{array}{l}\text { Total } \\
\chi^{2}=17.27(\mathrm{p}\end{array}$ & 001) & 99 & 47.14 \\
\hline
\end{tabular}

Note: ** Significant at $\mathrm{P}<0.001$

Table.3 Various biochemical parameters in control and PPR infected goats (mean \pm SE)

\begin{tabular}{llccc}
\hline Sr. No. & Parameters & $\begin{array}{c}\text { Seronegative } \\
(\mathbf{n = 1 1 1})\end{array}$ & $\begin{array}{c}\text { Seropositive } \\
(\mathbf{n = 9 9 )}\end{array}$ & P value \\
\cline { 2 - 5 } & \multicolumn{4}{c}{ Mean \pm SE } \\
\hline 1. & Creatinine & $1.06 \pm 0.03$ & $1.20 \pm 0.02 *$ & $<0.01$ \\
2. & ALP & $201.17 \pm 16.49$ & $304.83 \pm 36.98^{*}$ & $<0.01$ \\
3. & AST & $137.08 \pm 5.32$ & $122.56 \pm 7.20^{\mathrm{NS}}$ & 0.10 \\
4. & ALT & $26.88 \pm 1.81$ & $34.53 \pm 0.88^{* *}$ & $<0.001$ \\
\hline Note: ** -Highly significant at $\mathrm{P}<0.001$ & \\
*-Significant at $\mathrm{P}<0.01$ & &
\end{tabular}


The detail values (Mean \pm S. E.) of various parameters are presented in table 1 . In present study a total 210 blood samples were analysed for hematological analyses. Among them 99/210 blood samples were from seropositive goats and all the rest (111/210) were from seronegative goats. The mean \pm $\mathrm{SE}$ values of individual parameters of seropositive goats compared with seronegative goats and interpretation of result shown significant decrease in $\mathrm{Hb}, \mathrm{PCV}$, monocytes and MCV value of seropositive group when compared with seronegative group.

Remaining other hematological parameters i.e. TEC, TLC, neutrophiles, eosinophils, basophils, lymphocytes, $\mathrm{MCH}$ and $\mathrm{MCHC}$ did not show any significant variation between seropositive and seronegative group.

Ayatekin et al., (2011), Das et al., (2015) and Sharma et al., (2015) also reported decreased values of $\mathrm{Hb}$ and PCV in PPR infected goats in their study. Besides these, MCV significantly decrease in seropositive groups when compare to seronegative group. But Ayatekin et al., (2011) observed increased MCV values in seropositive group. Significantly decreased $\mathrm{Hb}$ and PCV values might be due to haemorrhages in various organs which may also results in anemic condition. Along with this monocytes also significantly decrease in seropositive group and supported the observation of Das et al., (2015).

Total 210 serum samples were subjected to various biochemical parameters among them 99 samples were from seropositive goats and rest were from seronegative goats. Evaluated mean \pm SE values of biochemical parameters were presented in table 3. Among biochemical parameters, ALT, ALP level and creatinine value were increased significantly in seropositive groups of animals. This is in accordance with the observations of Sahinduran et al., (2013).

Whereas, Ayatekin et al., (2011) reported increased ALT and Das et al., (2015) reported increased creatinine level only in serum of infected group.

Biochemical alteration in serum might be due to the infection of PPR virus which infect the organs and alter the function of liver and kidney (Das et al., 2015).

\section{Acknowledgements}

The authors are highly thankful to the Dean and Principal for providing facilities and fund. Authors also wish to thank Dr. I. H. Kalyani, Associate Professor and Head, Department of Veterinary Microbiology and Dr. J. M. Patel, Assistant Professor, Department of Veterinary Pathology, Vanbandhu College of Veterinary science \& Animal Husbandry, Navsari Agricultural University, Navsari, Gujarat, India for their guidance in screening serum samples.

\section{References}

Abd El-Rahim, I. H. A., Sharawi, S. S. A., Barakat, M. R. and Nahas, E. M., 2010. An outbreak of peste des petits ruminants in migratory flocks of sheep and goats in Egypt in 2006. Revue Scientifique ET Technique De L Office International Des Epizooties, 29(3): 655-662.

Afera, B. Hussien, D. and Amsalu, K., 2014. Seroprevalence of Peste Des Petits Ruminants in Goats of Southern Parts of Tigray Region. Global Veterinaria, 12(4): 512-516.

Ayatekin, I., Mamak, N., Ulucan, A. and Kalinbacak A., 2011. Clinical, hematological, biochemical and pathological Findings in lambs with 
Peste des petits Ruminants. Kafkas Universitesi Vetriner Fakiiltesi Dergisi, 17(3): 49- 55.

Balamurugan, V., Saravanan, P., Sen, A. Rajak, K. K., Venkatesan, G., Krishnamoorthy P., Bhanuprakash, V. and Singh, R. K., 2012. Prevalence of peste des petits ruminants among sheep and goats in India. Journal of Veterinary Science, 13(3): 279-285.

Balamurugan, V., Saravanan, P., Sen, A., Rajak, K. K., Bhanuprakash, V., Krishnamoorthy, P. and Singh, R. K., 2011. Sero-epidemiological study of peste des petits ruminants in sheep and goats in India between 2003 and 2009. Revue Scientifique ET Technique, 30(3): 889- 896.

Begum, S. S., Mahato, G., Sharma, P., Sharma, K., Hussain, M., Das, B. C., Hussain, J., De, A., Choudhary, D., Ramkrishnan, A. M. and Muthuchelvan, D., 2016. Seroprevalence of Peste des petits ruminants in goats in Assam, India. Asian Journal of Animal and Veterinary Advances, 11: 210-212.

Bello, A. M., Lawal, J. R., Dauda, J., Wakil, Y., Lekko, Y. M., Mshellia, E. S., Ezema, K. U., Balami, S. Y., Waziri, I. and Mani1, A. U., 2016. Research for Peste des Petits Ruminants (PPR) Virus Antibodies in Goats, Sheep and Gazelle from Bauchi and Gombe States, North Eastern Nigeria. Direct Research Journal of Agriculture and Food Science, 4 (8): 193-198.

Chandrahas, S., Chandel, B. S., Chauhan, H. C. and Dadawala, A. I., 2011. Seroprevalence of PPR in sheep and goats of North Gujarat. Indian Journal of Small Ruminants, 17(1): 118-121.

Chauhan, H. C., Dadawala, A. I., Chandel, B. S., Kalyani, I. H., Patel, S. S. and Kher, H. N., 2012. Seroprevalence of peste des petits ruminants in small ruminants under different managemental conditions. Indian Journal of Field Veterinarians, 7(3): 37- 39.

Chavan, V., Digraskar, S. and Bedarkar, S., 2009. Seromonitorting of peste des petits ruminants' virus (PPR) in goats of Parbhani region of Maharasta. Veterinary World, 2: 299-300.

Das, S., Nath, R., Balamurugan, V., Choudhury, R. and Devi, M., 2015. Haemato- Biochemical Analysis Of Goats Naturally Infected With Peste Des Petits Ruminants. International Journal for Research in Emerging Science and Technology, 2(9): 19-24.

De, A., Debnath, B., Dutta, T. K., Shil, S., Bhadouriya, S., Chaudhary, D., Rajak, K. K., Pachauri, R., Ramakrishnan, M. A. and Muthuchelvan, D., 2016. Seroepidemiology of peste-des-petitsruminants in goats of Tripura state of North-East India. Advances in Animal and Veterinary Sciences, 4(5): 215-217.

El-Yuguda, A., Baba, S. S., Ambali, A. G. and Egwu, G. O., 2013. Seroprevalence of peste des petits ruminants among domestic small and large ruminants in semi-arid region of north-eastern Nigeria. Veterinary World, 6(10): 807811.

El-Yuguda, A., Baba, S. S., Ambali, A. G. and Egwu, G. O., 2013. Seroprevalence of peste des petits ruminants among domestic small and large ruminants in semi-arid region of north-eastern Nigeria. Veterinary World, 6(10): 807811.

Gargadennec, L. and Lalanne, A. L., 1942. A peste des petits ruminants. Bull Serve Zootech Epizoot Afr Occid Fr, 5:16- 21.

Gibbs, E. P., Taylor, W. P., Lawman, M. J. P. and Bryant, J., 1979. Classification of peste des petits ruminants' virus as the fourth member of the genus morbillivirus. Intervirology, 11(5): 268274.

Govindarajan, R., Koteeswaran, A., 
Venugopalan, A. T., Shyam, G., Shaouna, S., Shaila, M. S. and Ramachandran, S., 1997. Isolation of peste des petits ruminants' virus from an outbreak in Indian buffalo (Bubalus bubalis). Veterinary Research, 141(22): 573- 574.

Hinshu, V., Kher, N., Jhala, S. and Chandel, M.K., 2001. Seroprevalence of Peste des petits ruminants (PPR) in Gujarat. Indian J. Comp. Journal of Microbiology, Immunology and Infection diseases, 22 (1): 81.

Jubb, Kennedy and Palmer, 2007. Pathology of Domestic Animal, $5^{\text {th }}$ edn, China Elsevier Ltd., Pp 150- 151.

Kanani, A., Sutariya, P., Shukla, R. and Shukla, R., 2006. Seroprevalence of Peste des petits ruminants (PPR) in small ruminants of Gujarat State. Indian Journal of Field Veterinarians, 1(4): 22- 23.

Kataria, A. K., Kataria, N. and Gahlot, A. K., 2007. Large scale outbreaks of Peste des Petits Ruminants in sheep and goats in Thar Desert of India. Slovenian Veterinary Research, 44: 123- 132.

Kumar, A., Singh, S. V., Rana, R., Vaid, R. K., Misri, J. and Vihan, V. S., 2001. PPR outbreak in goats: epidemiological and therapeutic study. Indian journal of animal science, 71(9): 815-812.

Mahajan, S., Agrawal, R., Kumar, M., Mohan, A. and Pande, N., 2013. Incidence of Peste des petits ruminants in nomadic sheep and goat of Jammu region, Veterinary World, 6(7): 384387.

Nagraj, 2006. Assessment of different gene target for detection of Peste des petits ruminants by RT-PCR and Sequence analysis of $\mathrm{F}$ and $\mathrm{N}$ gene segments. M.V.Sc. thesis, AAU, Anand, Gujarat.

Nanda, Y. P., Chatterjee, A., Purohit, A. K., Diallo, A., Innui, K., Sharma, R. N., Libeau, G., Thevasagayam, J. A.,
Bruning, A., Kiching, R. P., Anderson, J., Barrett, T. and Taylor, W. P., 1996. The isolation of peste des petits ruminants' virus from Northern India. Veterinary Microbiology, 51(3-4): 207216.

Nizamani, A. R., Nizamani, Z. A., Umrani, A. P., Dewani, P., Vandiar, M. A., Gandahi, J. A. and Soomro, N. M., 2015. Prevalence of peste des petits ruminants' virus antibodies in small Ruminantsin sindh, Pakistan. The Journal of Animal and Plant Sciences, 25(6): 515-1519.

Radostits, O. M., Blood, D. C. and Gray, C. C., 2007. Veterinary Medicine: A text book of the diseases of cattle, horse, sheep, pigs and goats. London: Elsevier, 10: $1242-1243$.

Raghavendra, A. G., Gajendragad, M. R., Sengupta, P. P., Patil, S. S., Tiwari, C. B., Balumahendiran, M., Sankri, V. and Prabhudas, K., 2008. Seroepidemiology of peste des petits ruminants in sheep and goats of southern peninsular India. Revue scientifique ET technique, 27: 861-867.

Rahman, A., Abubakar, M., Rasool, M. H., Manzoor, S., Saqalein, M., Rizwan, M., Munir, M., Ali, Q. and Wensman, J. J., 2016. Evaluation of Risk Factors for Peste des Petits Ruminants Virus in Sheep and Goats at the WildlifeLivestock Interface in Punjab Province, Pakistan. BioMed Research International, 2016: 1- 6.

Rahman, A., Yousaf, F., Anwar, N. and Abubakar, M., 2017. Serological detection of peste des petits ruminants' virus (PPRV) in sheep and goats of Muzaffargarh district in South Punjab, Pakistan. Veterinary Sciences: Research and Reviews, 2(3): 82-88.

Saha, A., Lodh, C. and Chakraborty, A., 2005. Prevalence of PPR in goats. Indian Veterinary Journal, 82: 668- 669. 
Sahinduran, S., Albay, M. K., Sezer, K., Ozmen, O., Mamak, N., Haligur, M., Karakurum, C. and Yildiz, R., 2013. Coagulation profile, haematological and biochemical changes in kids naturally infected with peste des petits ruminants. Tropical Animal Health and Production, 44(3): 453-457.

Santhosh, A., Raveendra, H., Isloor, S., Gomes, R., Rathnamma, D., Byregowda, S., Prabhudas, K. and Renikprasad, C., 2009. Seroprevalence of PPR in organised and unorganised sectors in Karnataka. Indian Veterinary Journal, 86: 659- 660.

Shaila, M. S., Purushothaman, V., Bhavasar, D., Venugopal, K. and Venkatesan, R. A., 1989. Peste des petits ruminants in India. Veterinary Record, 125: 602.

Sharma, K. K., Kshirsagar, D., Kalyani, I., Patel, D., Vihol, P. and Patel, J., 2015. Diagnosis of peste des petits ruminants' infection in small ruminants through in- house developed Indirect ELISA: Practical considerations. Veterinary World, 8(4): 443- 448.

Sharma, K. K., Kshirsagar, D., Kalyani, I., Patel, D., Vihol, P. and Patel, J., 2015. Diagnosis of peste des petits ruminants' infection in small ruminants through in- house developed Indirect ELISA: Practical considerations. Veterinary World, 8(4): 443- 448.

Singh R. P., Saravanan P., Sreenivasa B. P., Singh R. K. and Bandyopandhya S. K., 2004. Prevalence and distribution of the peste des petits ruminants' virus infection in small ruminants in India. Revue scientifique ET technique, 23: 807- 819.

Singh, R. K., Balamurugan, V., Bhanuprakash, V., Sen, A., Saravanan, P. and Yadav, M. P., 2009. Possible control and eradication of peste des petits ruminants from India: technical aspects. Veterinaria Italiana, 45: 449462.

Thakor, R. B., Patel, M. D., Patel, R. M. and Kalyani, I. H., 2016. Seroprevalence of peste des petits ruminants in goats of South Gujarat. Indian Journal of Small Ruminants, 22(2): 252-254.

Tiwari, A., 2004. Prevalence of Peste des Petits ruminants (PPR) virus in small ruminants of Gujarat and its characterization by RT-PCR/ RFLP and SSCP profiles. M.V.Sc. thesis, AAU, Anand, Gujarat.

\section{How to cite this article:}

Yash R. Patel, Jignesh M. Patel, Priti D. Vihol, I. H. Kalyani, Pramod S. Sakare, Pratik P. Panchal and Kaushik D. Thakor. 2017. Seroprevalence of Peste des Petits Ruminants (PPR) in Navsari and Valsad Districts of South Gujarat. Int.J.Curr.Microbiol.App.Sci. 6(8): 221-228. doi: https://doi.org/10.20546/ijcmas.2017.608.030 